\title{
Tissue engineering strategies for the induction of angiogenesis using biomaterials
}

\author{
Shirin Saberianpour ${ }^{1,2}$, Morteza Heidarzadeh ${ }^{1}$, Mohammad Hossein Geranmayeh ${ }^{3}$, Hossein Hosseinkhani ${ }^{4}$, \\ Reza Rahbarghazi ${ }^{1,5^{*}}$ (D) and Mohammad Nouri ${ }^{2,1,5^{*+}}$
}

\begin{abstract}
Angiogenesis is touted as a fundamental procedure in the regeneration and restoration of different tissues. The induction of de novo blood vessels seems to be vital to yield a successful cell transplantation rate loaded on various scaffolds. Scaffolds are natural or artificial substances that are considered as one of the means for delivering, aligning, maintaining cell connection in a favor of angiogenesis. In addition to the potential role of distinct scaffold type on vascularization, the application of some strategies such as genetic manipulation, and conjugation of proangiogenic factors could intensify angiogenesis potential. In the current review, we focused on the status of numerous scaffolds applicable in the field of vascular biology. Also, different strategies and priming approaches useful for the induction of pro-angiogenic signaling pathways were highlighted.
\end{abstract}

Keywords: Scaffolds, Vascular regeneration, Cell source, Genetic and proteomic manipulation, Delivery methods

\section{Introduction}

With regard to the function of many types of cells in restoring tissue performance, regenerative medicine with palliative treatments would be considered as an alternative medicine for the replacement or regeneration of various tissues and organs. Regenerative medicine uses different technologies and methodologies including; tissue engineering techniques, cell transplantation approach, stem cell biology, biomechanics, prosthetics, and nanotechnology [1]. By using appropriate physical substrates and the induction of cellular signaling pathways, these novel approaches provide the basic interaction and essential integration of plated cells with underlying biomaterials scaffolds and crosstalk with the neighboring cells. Up to the present, diverse methodologies and approaches have been found in this era (Table 1). In the construction of tissue-engineered grafts, it seems that

\footnotetext{
*Correspondence: Rezarahbardvm@gmail.com; rahbarghazir@tbzmed.ac.ir; Nourimd@yahoo.com

${ }^{\dagger}$ Reza Rahbarghazi and Mohammad Nouri contributed equally to this work. ${ }^{1}$ Stem Cell Research Center, Tabriz University of Medical Sciences, Imam Reza St., Golgasht St, Tabriz 5166614756, Iran

${ }^{2}$ Department of Molecular Medicine, Faculty of Advanced Medical Sciences, Tabriz University of Medical Sciences, Tabriz, Iran

Full list of author information is available at the end of the article
}

the promotion of vascularization and angiogenesis is a fundamental step for efficient organ reconstitution and replacement [2]. The progression and development of blood vessels into the transplanted tissues are stimulated following induction of pro-angiogenic signaling pathways. In line with this statement, controlling the angiogenic switch and vessel development is essential for the normal activity of transplanted cells and/or acquisition of novel phenotypes. Angiogenesis status is determined by the balance between pro- and anti-angiogenesis factors and cytokines [3]. It has been determined that the in situ production of pro-angiogenic factors promotes the vascular regeneration in response to tissue demands [4]. Early-stage angiogenesis is promoted due to the secretion of most important factors VEGF, bFGF, Ang-2 and other ligands by different cells located in the close proximity to target sites and remote areas. Following the angiogenic switch, the expression of receptor tyrosine kinases such as VEGFR-2 and Tie-2 along with Tie-1 is up-regulated on ECs surfaces thereby promotes intracellular signaling pathways [5]. After the induction of ECs by pro-angiogenic factors, the cell-to-cell connection is weakened which followed by degradation of basal membrane governed by the activation of MMP-2 and -9 [6]. 
Table 1 Progress in the field of regenerative medicine

\begin{tabular}{ll}
\hline Finding/Experiment & Ref. \\
\hline First cell transplantation: Bone marrow transplant (1968) & {$[116]$} \\
Discovery of stem cells in human cord blood (1978) & {$[117]$} \\
First engineered tissue transplantation: skin (1981) & {$[118]$} \\
First in vitro stem cell line developed from mice (1981) & {$[119]$} \\
First engineered vessel structure was synthesized (1986) & {$[120]$} \\
Adult stem cells were used for vascular regeneration by & {$[121]$} \\
Asahara (1997) & \\
Isolation of human embryonic stem cells (1998) & {$[122]$} \\
$\begin{array}{l}\text { First laboratory-grown organ: an artificial bladder implanted } \\
\text { in a patient suffering from myelomeningocele (1999) }\end{array}$ & {$[123]$} \\
$\begin{array}{l}\text { Implantation of first engineered tubular organs } \\
\text { (urine conduits) (2004) }\end{array}$ & {$[124]$} \\
$\begin{array}{l}\text { Discovery of stem cells derived from amniotic fluid and } \\
\text { placenta (2007) }\end{array}$ & {$[125]$} \\
First solid organ engineered by recycling donor liver (2009) \\
$\begin{array}{l}\text { 3D-printed vascular networks direct therapeutic angiogenesis } \\
\text { in ischemic condition (2017) }\end{array}$ & {$[123]$} \\
\hline
\end{tabular}

Activated ECs proliferate and migrate in response to the concentration gradient of pro-angiogenic factors. Two EC types are phenotypically detectable based on the cell surface markers; tip cells, CD34, and CD31 positive cells, that are located at the sprout tips and characterized by the existence of filopodial extensions and stalk ECs, CD31 positive and CD34 negative cells, constitute the lumen of nascent vessels [7]. To stabilize the vessel structure, the attachment of Ang-1 to cognate receptor Tie-2 increases the integration of ECs with neighboring cells and surrounding peri-vascular pericytes thereby promoting vascular maturation and reducing migration activity of ECs. In addition to angiogenesis initiated by sprouting mechanism, other alternative remodeling mechanisms such as intussusception and bridging were also described as inverted angiogenesis in the context of vascular structure [8]. Intussusception is touted as trans-vascular tissue pillars formed inside vessels lumen extensively seen in developing vessels to form multi-vascular branches. In bridging vascular remodeling, intraluminal endothelial bridges are formed by invagination of the basal membrane while incorporating polarized ECs with simultaneous cytoskeletal adaptation from both sides to each other thereby dividing the luminal space into multi-vascular units [9]. It is well known that the ECM composition, stiffness could affect ECs functional behavior, differentiation, and network formation properties. Alteration of ECM consistency and substrate composition caused to ECs lose tubulogenesis capacity and changes migration activity. Mechanical stimuli can affect the expression of genes participating in angiogenesis signaling pathways. After cell adaptation to mechanical forces induced by surrounding environment, the emergence of internal and external forces dictates location and shape of organelles and biomolecules and their interaction with cell cytoskeleton, resulting in the adaptation of biochemical responses and angiogenesis modulation [10]. Controllable angiogenesis induction will enable us to increase the final extent of transplanted tissue to host tissues. This review article familiarizes the readers with the different scaffolding biomaterials that have been used for the restoration of vascular structure in a different milieu and novel approaches applicable to harness the angiogenic potential of biomaterials in different contexts.

\section{Vasculogenesis and angiogenesis; terminology and definitions}

There are two fundamental primary mechanisms implement the formation of new blood vessels; vasculogenesis and angiogenesis [11]. The formation of fetus heart and primary vascular network from yolk sac is governed by vasculogenesis while angiogenesis mainly participates in vascular remodeling post-natal period [11]. In response to cytokines gradient, EPCs recruit to target sites and participate to restore luminal continuity [12]. The critical role of EPCs has been documented during fetal growth and development [13]. Angioblasts are the primary source of ECs at the early-stage development of fetus with a great capacity to differentiate into functional ECs. These cells form clusters to generate tube-like structures which are further supported by cells expressing $\alpha$-actin namely $\alpha$-SMCs [14-16]. Cells expressing $\alpha$-SMC maintains vascular integrity and the tight junction with ECs at the luminal surface by the synthesis of collagen and ECM substrates such as elastin. These fibers give an opportunity for vessels to preserve contractility and increase mechanical resistance [17]. To induce the generation of de novo blood vessels, proteases degrade the ECM at the site of angiogenesis $[18,19]$. During the promotion of an active angiogenesis status, vessel branching occurs in three distinct stages as follows; quiescence, activation, and resolution. In the stage of quiescence, cell proliferation is inhibited when ECs are in close contact with VE-cadherins from neighboring cells. The persistent interactions are intensified by the activity of surrounding pericytes. Following the angiogenic switch, for example, the production of angiogenesis factors such as VEGF, it facilitates pericytes detachment from the basement membrane and therefore ECs have enough space to migrate to the target sites. The accelerated degradation of basement membrane paves the ground for extending ECs to migrate [20]. Considering the important role of blood vessels in the nourishment of various cells, it is believed that providing novel techniques to promote large-scale angiogenesis with distinct growth factor are key factors for successful engineering of large organs [21, 22]. 
The application of cells for the induction of angiogenesis The application of SCs for vascular regeneration and the existence of pro-vasculogenic EPC subpopulation have been extensively used in recent clinical trials [23]. These cells have per se potential to modulate the function of blood vessels in different trials. In support of this statement, scientists have strived to exploit the pro-angiogenic ability of EPCs for treating myocardial infarction, ischemic changes, and peripheral vascular disease and wound healing as well $[20,24]$. After initiation of ischemic changes, there is an urgent need for the pro-angiogenic activity of transplanted cells on engineered vascular constructs while inhibiting angiostatic pathways [25]. The advent of novel approaches must be able to afford the pitfalls and drawbacks correlated with classical therapeutic methods. For instance, the most prevalent clinical solution for heart attack is the replacement of injured vessels with autologous vein and arteries to restore blood supplementation [26]. Considering disease management and pathological changes associated with age, bulks of patients without normal vessels are candidates for the vessels grafting. For example, the lack of inappropriate angiogenesis rate contributes to non-completed cardiac tissue restoration caused by ischemia and hypoxia. Therefore, an essential clinical management is required to efficiently perfuse blood to the ischemic sites through the promotion of angiogenesis by engaging pro-angiogenic effectors. Noteworthy, the induction of vessels formation from pre-existing vasculature bed and recruitment of EPCs and CECs could be an appropriate strategy in favor of vasculogenesis [27, 28]. Along with the control of angiogenesis signaling pathway and the dynamics of participant cells, fabrication of physiological microenvironment via a plethora of semi-synthetic and synthetic scaffolds similar to in vivo condition is inevitable. In this regard, the application of various strategies for the synthesis of vascular grafts via a suitable semi- and natural substrates, appropriate cell phenotypes, factors, and mechanical changes are inevitable [29]. Calling attention, scaffolds fabricated from biomaterials with different composition formula and mechanical properties have great potentials to regulate the development of vascular tissue.

\section{The application of various cell types for vascular tissue engineering}

There are two main issues in vascular regenerative medicine therapy. The first one deals with the synthesis of engineered vessels and the second one is involved in the introduction of tissue constructs in promoting the growth of novel vascular networks by engaging pro-angiogenic factors. Each of these approaches seems to be effective to improve neovascularization. Due to the available cellular source in the context of angiogenesis, three main categories are routinely accepted; (a) somatic cells and (b) stem cells (either embryonic or adult cell type) and (c) iPSCs. In this regard, different cells from various tissues were applied to restore angiogenesis and function of ECs (Fig. 1). However, most common vascular cell types are applied for vascular regeneration include ECs, $\alpha$-SMCs, pericytes, and EPCs with a strong angiogenic potential. Both allogeneic and autologous cells from mature vascular cells, including ECs and SMCs, were transplanted to subjects. Other cell types such as MSCs and iPSCs are increasingly used in numerous experiments to induce angiogenesis. Due to the lack of an immunogenic response or cell rejection upon implantation, the application of host cells is most convenient and more suitable for vascular engineering rather than the allogeneic counterpart. Compared to the progenitor cells, mature vascular cells possess a limited proliferation capacity, contributing to limited restorative effects and a low rate of pro-angiogenic outcomes [30-32]. As above-mentioned, the application of both ECs and EPCs seems to be useful for the induction of vessels formation. However, due to a high rate proliferation capacity, EPCs could promote angiogenesis efficiently compared to the mature counterpart.

\section{Application of ESCs in the context of angiogenesis}

ESCs could be isolated from blastocysts inner cell mass having the ability to give rise to any cell type and to produce endodermal-, mesodermal-, and ectodermalderived lineages and SCs [33]. Recent researches indicated an inherent ability of ESCs in differentiating into EC-, $\alpha$-SMC- and cardiomyocyte-like cells as well [34]. During endothelial differentiation of ESCs, cell distribution of specific markers such as CD31 (PECAM), von Willebrand factor is increased. For functional analysis, different assays notably, acetylated-LDL uptake, in vitro tubulogenesis on $\mathrm{Matrigel}^{\circ}$ and various protein substrates, staining with lectin and etc. have been introduced yet [35]. Compared to SCs, ESCs show a higher stemness feature and proliferative capacity [36]. Nonetheless, clinical applications of ESCs have some ethical issues related to the use of human embryos. Also, different immunological responses could be seen after the introduction of these cells to the target tissues. As a matter fact, it does necessitate prescribing immunosuppressive agents prior to administration of ESCs and progenies [37]. The combined regime of ESC-ECs sources has not been completely approved so far for vascular regeneration and is under early-stage trials development. Overall, it takes time to get allowable credits and translate the application of ESC for subjects with cardiovascular disease [38, 39]. 


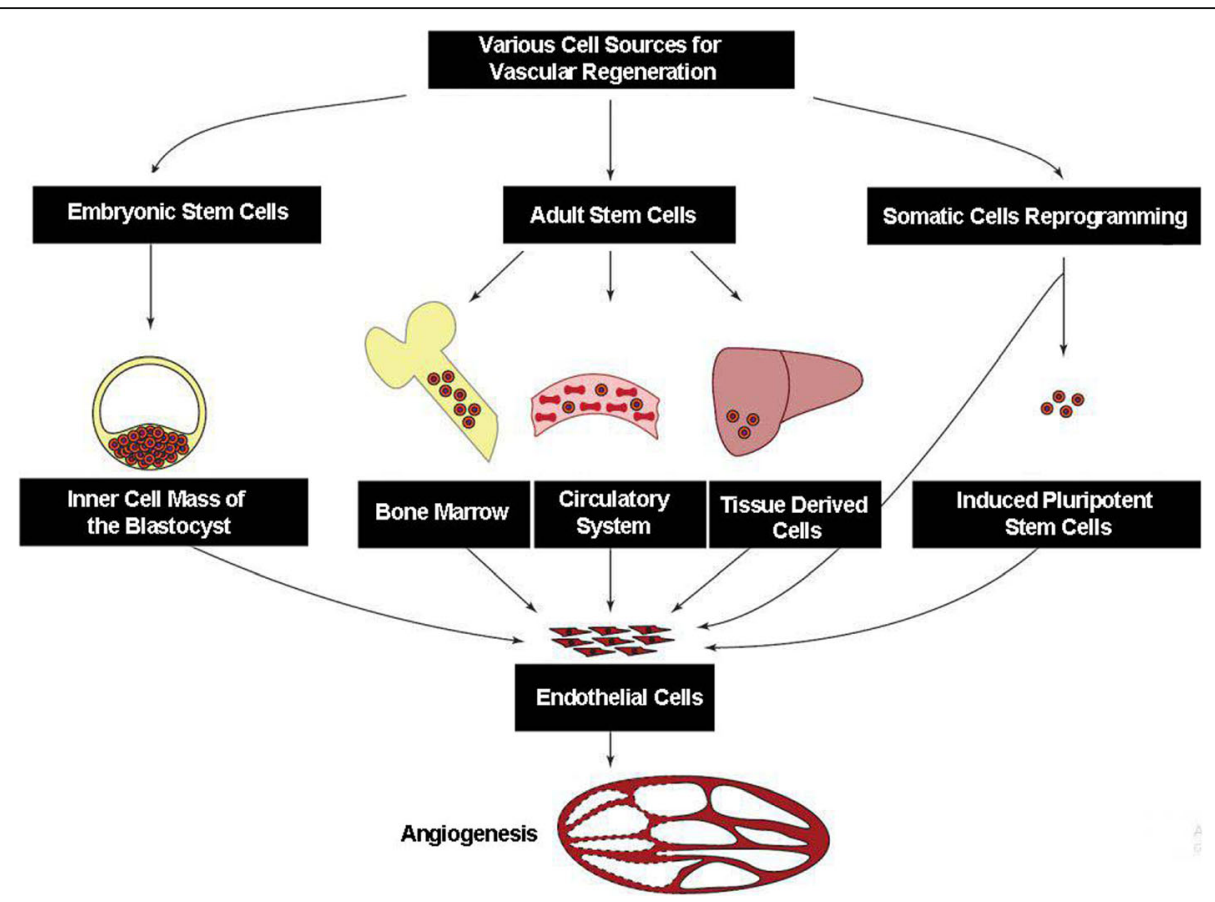

Fig. 1 Various cell sources used at the current for vascular regeneration or induction of Angiogenesis. Many cell sources are applicable to regenerate various tissues by affecting angiogenesis and blood support

\section{SCs}

With particular success in the treatment of hematopoietic malignancies, SCs have been administrated for therapeutic use [40]. In the 1950s and 1960s, hematologists demonstrated that transplantations of bone marrow HSCs could generate a new immune system composed of many distinct functional cells. It is thought that these cells have some limitation compared to other SCs. MSCs, fibroblastlike cells, can be grown easily in in vitro condition in contrast to HSCs [31]. MSCs can be selectively differentiated into osteocyte-, adipocyte-, and chondrocyte-like cells by the modulation of various growth factors and cytokines in distinct time points [41]. A number of limitations are, however, seen in in vitro and in vivo milieu. For instance, the number of SCs are so trivial and their trans-differentiation capacity decreases by aging meanwhile the control of cell-to-cell commitment is out of control [42]. For example, a number of EPC subpopulation undergoes endothelial differentiation [43]. As a matter of fact, new approaches and strategies must be invented to dictate angiogenesis potential of each cell type. Enhancing the recruitment of progenitor cells to distinct sites, implementation of cell-to-cell crosstalk and promotion of cells alignment with vascular grafts and conduits should be determined on ongoing investigations [32].

\section{iPSCs and their application}

The emergence of iPSCs is considered an interesting phenomenon in regenerative medicine, paving a splendid avenue for the reconstitution of cardiac and vascular systems [44]. iPSCs are the most appropriate cell source with a great potency to giving rise to cardiomyocytelike cells, mural cells and ECs [45]. The generation of iPSCs is achieved by the modulation of Yamanaka factors genes inside adult somatic cells, including Oct-4, Sox-2, c-Myc, and Klf-4. Cells show pluripotency properties similar to ESCs after induction of above-mentioned genes [38]. Numerous attempts have been done to investigate the vascular differentiation of iPSCs and application to human vascular research. The more recently researchers indicated that re-programming factors are sufficient to orient adult cells differentiation into the un-differentiated state. Basically, iPSCs are found to trans-differentiate into three germ layers. The therapeutic potential of iPSCs is mighty as they are patientspecific SCs hamper the immunological responses which seen in cells originated from ESCs. A plethora of experiments showed an inherent capacity of various cell types in the induction of iPSCs. The donor's skin, fat or hair are easily accessible sources of cells [46]. Considering the lack of immunological responses, it seems that iPSCs do not have some limitation related to ESCs but the generation of iPSCs is laborious. In addition, iPSCs posse much less potential compared to the ESCs.

SCs delivery systems used in vascular regeneration Researchers have so far sought to investigate the best applicable methods for SCs delivery to attain the most 
therapeutic effects. The primary objective in this field is to ensure an accurate homing of the transplanted cells to ischemic areas and to prolong the survival and retention of cells post-administration. More than $90 \%$ of cells are cleared from the transplantation sites during $24 \mathrm{~h}$ and this value is thought to reach $1 \%$ 4-week posttransplantation [47]. Because of hazardous operations, non-invasive methods are being considered as well. Novel methods and delivery approaches with inherent advantages and disadvantages having been approached for the delivery of SCs [48] (Table 2).

The promotion of vascularization by scaffolds In support of angiogenesis, various scaffolding biomaterials are widely applied in tissue engineering to promote pro-angiogenic signaling pathways [46]. Scaffolds have been used for increasing the rate of transplantation outcomes and collaboration of extrinsic cells with host niche in a three-dimensional mode $[49,50]$. In the case of angiogenesis, factors such as VEGF can be bound to scaffolds surface with sustained release to the surrounding tissue. Of multiple types of biomaterials, injectable scaffolds show a promising approach to promote angiogenesis. Compared to conventional surgical techniques, hydrogel scaffolds are less invasive and can be easily shaped to fill cavities and the areas of necrotic tissues [50]. Various materials with natural and synthetic structures are used to promote angiogenesis. Considering reproducibility and accessibility, synthetic materials are likely for medical translation services. The fabrication of synthetic scaffolds using different methodologies enables us to control some properties of physicochemical properties such as the elasticity and degradation rates [51]. Generally, synthetic materials are fabricated reasonable degradability at the same rate of tissue healing and growth. Natural scaffolds are commonly prepared from ECM substitutes mainly collagens, HA and fibronectin. Single purified substrates or the combined ECM proteins could be used along with decellularized ECM harboring specific cell type. The conjugation of single purified peptides and combinations of single proteins with decellularized ECM is done by using cell extract or tissue samples [52]. Due to the existence of natural analogs and distinct molecular arrangement, scaffolds formulated with ECM components are sufficient to provide anchoring-type attachment, cell growth, and trans-differentiation into various lineages. In addition, no harmful degradation products are produced which in turn enhances scaffolds integration with the body. On the other hand, control of the degradation rate, strength, and elasticity are laborious and complicate [53]. Some pitfalls of scaffolding and their applications are outlined in Table $3[54,55]$.

Table 2 Different cell delivery methods for the regeneration of target organs

\begin{tabular}{|c|c|c|c|}
\hline Approach & Advantage & Limitation & Ref \\
\hline Scaffolds & $\begin{array}{l}\text { - Carrying cells } \\
\text { - Delivery pro-angiogenic factors } \\
\text { - Providing 3D condition } \\
\text { - Having stability }\end{array}$ & $\begin{array}{l}\text { - Timely degradation } \\
\text { - Toxicity } \\
\text { - Immune-modulatory effects }\end{array}$ & [127-130] \\
\hline $\begin{array}{l}\text { Stem cell priming or } \\
\text { pretreatment }\end{array}$ & $\begin{array}{l}\text { - Improve differentiation rate } \\
\text { - Improve migration and homing } \\
\text { rate to target tissue } \\
\text { - Improve cell function }\end{array}$ & $\begin{array}{l}\text { - Cellular senescence } \\
\text { - Critical consideration for } \\
\text { cell treatment }\end{array}$ & [131-136] \\
\hline Exosomes & $\begin{array}{l}\text { - Bio-shuttle for pro- and anti- } \\
\text { angiogenic factors } \\
\text { - Lack of immune-privileged } \\
\text { capacity }\end{array}$ & $\begin{array}{l}\text { - Promotes tumorgenesis } \\
\text { - Needs to isolate and } \\
\text { concentrated }\end{array}$ & [137-142] \\
\hline $\begin{array}{l}\text { Magnetic enhancement } \\
\text { techniques }\end{array}$ & $\begin{array}{l}\text { - Facilitate the cell retention rate } \\
\text { - Control cells mobilization into } \\
\text { target sites } \\
\text { - Track transplanted cells in in vivo }\end{array}$ & $\begin{array}{l}\text { - Provide micro-emboli for cells } \\
\text { with small size features }\end{array}$ & [143-145] \\
\hline Ultrasound techniques & $\begin{array}{l}\text { - Enhance delivery of cells to } \\
\text { target sites }\end{array}$ & $\begin{array}{l}\text { - Yields cytotoxicity by promoting } \\
\text { necrosis or apoptosis } \\
\text { - Tissue damage such as arrhythmias, } \\
\text { endothelium malfunction such as } \\
\text { capillary leakage }\end{array}$ & [146-148] \\
\hline Enhanced homing technique & $\begin{array}{l}\text { - Enhance proliferating, migrating, } \\
\text { and alignment of EPCs to } \\
\text { target sites }\end{array}$ & $N D^{*}$ & {$[146,149]$} \\
\hline Mannitol-enhanced delivery & $\begin{array}{l}\text { - Used for cell delivery through } \\
\text { the blood-brain barrier }\end{array}$ & $\begin{array}{l}\text { - Being selective for distinct } \\
\text { cells and factors }\end{array}$ & {$[48,150-152]$} \\
\hline
\end{tabular}


Table 3 Desirable features for biomaterials

\begin{tabular}{ll}
\hline Characteristics & Index \\
\hline Biocompatibility & $\begin{array}{l}\text { Rejection, Inflammation, Immune } \\
\text { responses } \\
\text { To template }\end{array}$ \\
High surface area & $\begin{array}{l}\text { Initial cell number for plating, Cell } \\
\text { and surface interaction, Cell growth } \\
\text { and proliferation, and cell ability to } \\
\text { access oxygen and nutrients }\end{array}$ \\
Degradable & $\begin{array}{l}\text { Match the rate of tissue regeneration } \\
\text { to maintain tissue functionality } \\
\text { Consistency against to biological forces }\end{array}$ \\
Mechanical stretching & $\begin{array}{l}\text { Support the cells in synthesizing tissue- } \\
\text { specific extracellular matrix components } \\
\text { and growth factors required for healthy } \\
\text { tissue growth }\end{array}$ \\
factors cocktail & $\begin{array}{l}\text { To prevent cell cytotoxicity without } \\
\text { alteration in physical values }\end{array}$ \\
Stability & $\begin{array}{l}\text { To elicit a barrier between luminal and } \\
\text { body cavity } \\
\text { Serve as a barrier }\end{array}$ \\
Support the induction & $\begin{array}{l}\text { pattern to promote appropriate } \\
\text { innervation and vascularization }\end{array}$ \\
\hline
\end{tabular}

During the last decades, demands for vascular transplantation have been raised after the initiation of cardiovascular disease while rejection could be seen just after the transplantation. Lack of proper donors and failure in the process of surgical operations has led to increasing researchers in the field of vessel engineering and the production of the vascular grafts [56]. A scaffold can play an important role in tissue engineering and restoration. In recent decades, the use of biomaterials similar to vessels structure has been considered extensively by different authorities. Engineered vascular grafts require multiple factors to facilitate compatibility with natural veins and increase production functionality in vivo. Some of these features are considered for the development of vascular prosthesis. Characteristics such as proper porosity, a low rate of thrombogenicity and immunogenicity with minimum harmful effects on blood cells, enzymes, and plasma proteins should be notified in the fabrication of tissue-engineered vascular structures $[57,58]$. Additionally, biodegradation is one of the specific requirements for tissue-engineered grafts and determined by scaffold components and mechanical properties [59]. Cell attachment to scaffold moieties is essential for the activity of cells over a time thus substances in vessel grafts should have sufficient cell adhesion properties. The existence of bioactive moieties in scaffolds promotes the juxtacrine connection of ECs with pericytes and cells expressing factor $\alpha$-SMA [60]. Regarding the prevalence of cardiovascular disease and a higher mortality rate among old patients, investigations in heart and vessels transplantation techniques, design and use of appropriate biomaterials with the ability to preserve cell activity are highly needed.

\section{Biomaterials}

The term of the scaffold expresses a temporary structure that causes tissue growth and formation in the biological environment by providing a 3D environment. Creation of small biological environment will result in cell growth, differentiation and acquisition of specific phenotype. Scaffold materials can be classified into both natural and synthetic categories. The natural ECM substrates with specific particle diameter are highly dynamic and have complex interplay with cells. Scaffolds made of natural materials contain specific ligands for cellular connectivity, cell migration, and various growth factors to achieve a strong restoration rate. Based on the tissue compatibility and stiffness rate, various materials are commonly used for the restoration of specific organs (Table 4). As a result, the selection of materials depends on the target tissue consistency and defect severity [61-63]. From a certain point of view, scaffolds are biological materials with clues for the promotion of cell growth and tissue regeneration. In addition, enhancing the angiogenic potential of host tissue allows a higher degree of control on cell behavior after transplantation. Commensurate with these comments, scaffolds have the potential to harbor distinct growth factors, provide moieties for cell attachment and develop the 3D condition for cell-to-cell communication is highly recommended. These features enable scaffolds to efficiently induce angiogenesis and cell adaptation after transplantation into target sites.

\section{Collagen}

Features of collagen in scaffolds allow fabricating products with graded elastic stiffness. Despite these advantages, collagen breakdown products in vivo may cause to release of thrombogenic materials such as amino acids, resulting in an increase of immunogenic reactions. However, the most common problems with using collagen scaffolds are the high cost of earning a pure solution. Collagen is the most abundant protein in ECM synthesized by fibroblasts and bone osteoblasts $[63,64]$. Due to optimal stiffness property, collagen could be considered as an appropriate substrate for the synthesis of engineered vessel grafts. However, cautions must be taken related to the release of degradation products into systemic circulation.

\section{Elastin}

The shape and elasticity of blood vessels depend on the amount of elastin substrate. Scaffolds with small porosities made of the combination of elastin and collagen are suitable for fabricating small-diameter vessels. Compared to collagen, the insoluble form of elastin has 
Table 4 Advantage and limitation of different biomaterials in tissue-engineered approaches

\begin{tabular}{|c|c|c|c|}
\hline Scaffold & Advantage & Limitation & Ref \\
\hline Collagen & $\begin{array}{l}\text { - Highly distensible and pressure sensitive } \\
\text { - Having well-organized pattern } \\
\text { - Resistant to high strain and decrease the permeability } \\
\text { of the vascular structure }\end{array}$ & $\begin{array}{l}\text { - Thrombogenic potential and activation of the } \\
\text { coagulation cascade } \\
\text { - Enhanced risk of immunogenicity } \\
\text { - The high cost of pure collagen }\end{array}$ & [153] \\
\hline Elastin & $\begin{array}{l}\text { - Suitable for high porous structures with a small diameter } \\
\text { - Enhanced the proliferative capacity of ECs } \\
\text { - Enhanced cell dynamics and rearrangement of collagen } \\
\text { after tension }\end{array}$ & $\begin{array}{l}\text { - Solubilizing difficulty } \\
\text { - Inefficient mixing with other polymeric materials }\end{array}$ & [65] \\
\hline Matrigel & - Comparability to extracellular matrix & $\begin{array}{l}\text { - Minimally invasive } \\
\text { - Degradation time }\end{array}$ & [154] \\
\hline Fibrin & $\begin{array}{l}\text { Suitable for delivery of thrombin, fibrinogen and } \\
\text { coagulation factors }\end{array}$ & $\begin{array}{l}\text { - Structural weakness } \\
\text { - Suitable for the fabrication of synthetic transplants } \\
\text { (PEG, PLGA) }\end{array}$ & [69] \\
\hline Alginate & Used commonly polymer for encapsulation & Control of size & [74] \\
\hline Chitosan & Easily form polyelectrolyte complexes with other polyanions & Poor mechanical property & {$[75,155,156]$} \\
\hline Agarose & $\begin{array}{l}\text { Available as agarose, is gelatinous and has sol-gel transition } \\
\text { based on temperatures }\end{array}$ & A wide range of commercially available agarose & [157] \\
\hline HA & low HAs enhances the proliferation and migration of ECs & The high molecular HAs inhibits angiogenesis & [158] \\
\hline
\end{tabular}

higher strain recovery [65]. The proliferative potential of ECs was found to enhance by the mixture of elastin and collagen gels. Notably, scaffolds with elastin origin could enhance cell activity, rearrangement, stability, and mobility. In some experiments, it was demonstrated that the combination of elastin with other polymers could yield more solubilizing and transparent mixture compared to elastin scaffolds [66]. It seems that elastin could be applied for fabrication of small-diameter vascular grafts and its combination with other substrates is useful for the synthesis of large-diameter vascular units.

\section{Fibrin}

Fibrin can be isolated from patient blood and mix with scaffolds for therapy aims [67, 68]. Fibrin is a type of protein with a high density and potential for survival of transplanted cells. The application of fibrin in scaffolds is a traditional method for delivery of thrombogenic factors, bone marrow mononuclear cells and various cytokines such as bFGF [69]. In spite of the benefits, fibrin has some drawbacks, for example, the extra addition of fibrin causes structural weakness [70]. It is hypothesized that fibrin has a great potential to transfer growth factors and distinct cells to the target sites. Because of lytic susceptibility and thrombogenic activity, the application of fibrin has been limited in the structure of engineered vessels grafts.

\section{Alginate}

The most frequently used polymer for encapsulation of therapeutic agents is alginate. Alginate is the most studied material for encapsulation of living cells from different sources. Due to a unique feature and molecular structure, alginate has been extensively applied to increase angiogenesis and endothelial differentiation after combination with factors such as VEGF and bFGF. Despite an unregulated hemangioma formation and vascular leakage, small doses of alginate could bring therapeutic outcome without any complications. For example, alginate encapsulation of transplanted cells containing heparinized group provides prolonged sustained release of growth factors in infarct areas [7174]. However, alginate has an excessive negative charge, limiting the cell attachment and alignment. The combination of alginate with natural substrates could circumvent these pitfalls and limitations. In line with these claims, the application of alginate-based scaffolds must be considered after the completion of further investigations.

\section{Chitosan}

Chitosan, a type of polysaccharide termed as chitin, is extracted from exoskeleton in many species. Chitosan could be combined with other polyanions because of unique molecular properties. It was elucidated that the combination of chitosan/alginate (alginate bead) with poly-L-Lysine improves chitosan biodegradability and biocompatibility by changes in $\mathrm{pH}$ and solubility. In this regard, various structural modifications can also be chemically done on chitosan in favor of tissue engineering $[51,75]$.

\section{Scaffold-based miRNA therapy}

A large number of experiments showed that miRNAs can change the dynamic growth of SCs and somatic cells. These features were further determined by monitoring the expression and inhibition of specific miRNAs by complementary sequences $[76,77]$. 


\section{miRNA replacement therapy}

Differentiation is a process that causes to change the level of miRNA in stem cells and various cell types. In many surveys, this strategy is used for the orientation large-scale differentiation of progenitor cells by modulating the level of distinct miRNAs. Modulations are performed based on the application of miRNAs with two approaches; (I) Delivery of target miRNA that has the same sequence with double strand oligonucleotides, mimicking the same structure with the ability to enter miRISC complex and thereby intensify the content of target genes. (II) Introduction of specific genetic materials (miRNAs) inhibits the function of target genes. This model has a unique potential for sustained release of miRNA, however, a disadvantage such as off-target effects should not be neglected $[78,79]$.

\section{miRNA inhibition therapy}

The aim of miRNA inhibition therapy is to stop or decrease certain miRNA expression. In this regard, some methodologies are applied to destruct miRISC complex. The most direct way for inhibition between miRISC and miRNA is the application of AMO [80, 81]. However, this strategy may result in unwanted side effects because a single miRNA can regulate different genes. Therefore, miRNA masks are developed to minimize the off-target effects and selectively block specific mRNA pathway, contributing to the inhibition of specific protein [82].

\section{miRNA in angiogenesis}

miRNA is one of the most common factors for the induction/inhibition of angiogenesis. For instance, the overexpression of miRNA-503 in ECs leads to migration, proliferation, stimulation, and cell division via the modulation of cyclin E. In another study, cardiac ECs expressing miRNA-24 showed profound changes in the transcription level of ATA2, P21 kinase PAK4, apoptosis, and cell sprouting rate. It was showed that miRNA-24 could abort myocardial function and angiogenesis rate in mouse cardiac cells. Despite the benefits of angiogenesis, there is a close relationship between vascularity and tumor expansion. For example, a cluster of miRNAs (miRNA-17, $-18 \mathrm{a},-2 \mathrm{a},-19 \mathrm{~b}-1$, and -17-92) increase angiogenesis in both of in vivo and in vitro conditions. Nevertheless, miRNA application is enthusiastically welcomed for the induction of angiogenesis rather than repression [83-86]. Commensurate with these comments, it is logical to assume that two approaches, miRNA replacement, and induction, could be applied in the field of tissue-engineered vascular grafts and angiogenesis by modification of genetic elements in the target cells.

\section{miRNA delivery systems}

Different miRNA delivery systems have been established in the field of regenerative medicine (Fig. 2). Commonly methods for miRNA delivery are direct injection and the application of viral/non-viral vectors.

\section{Systemic miRNA delivery systems}

Viral vectors are another method for delivery of specific genomic pool to a large number of cells. Due to the susceptibility to degradation by RNase, the main pitfall of miRNA therapy pertains to short shelf-life period. Additionally, miRNA concentration decreases with the progression of cell division. Therefore, they only exert a transient silencing effect. The main barrier for clinical translation of the viral vector is a safety problem that was caused by immunogenicity and insertion mutagenesis. Different viral vectors have been approved yet, however, each of them can have own limitations and advantages. In the biological field, most popular viral vectors are adenoviral and AAV, lentiviral and retroviral vectors. AAV is the most commonly used between other viral vectors. This viral-vector is a non-enveloped virus that needs adenovirus for completing own amplification. This vector has single strand DNA with $4.7 \mathrm{~Kb}$ and 12 primate serotypes (AAV1-12). On the other hand, AAV with small size and non-pathogenicity for a human is an appropriate selection for delivery of miRNAs. Retroviruses are commonly used for cellular reprogramming and genetic manipulation $[80,86,87]$.

\section{Direct injection}

Direct systemic injection is the simplest method for delivery of miRNAs but the main problem for this way is short-term stability. In support of this notion, miRNAs are very sensitive and can be rapidly cleared by kidneys. They also attach to plasma proteins and/or degraded by nucleases enzymes in serum. Nonetheless, it has proven that the application of some miRNA inhibitors increases miRNAs stability and function following intravenous and subcutaneous injections. For instance, intravenous injection of LNA-anti-miRNA showed the silencing of miRNA-122 in the liver and the decrease of plasma cholesterol. It has also been indicated that a single bolus injection of LNA-anti-miRNA is active for several weeks $[88,89]$. In some circumstances, the direct injection of miRNAs could provoke immune response elements and thereby some strategies must be considered to limit unwanted immune reactions.

\section{Exosomal delivery}

Exosomes are nano-sized particles, ranging from 40 to $150 \mathrm{~nm}$, present in body fluids. They encompass specific biomolecules and specific genetic modulators that control numerous biological activities [90]. Considering the 


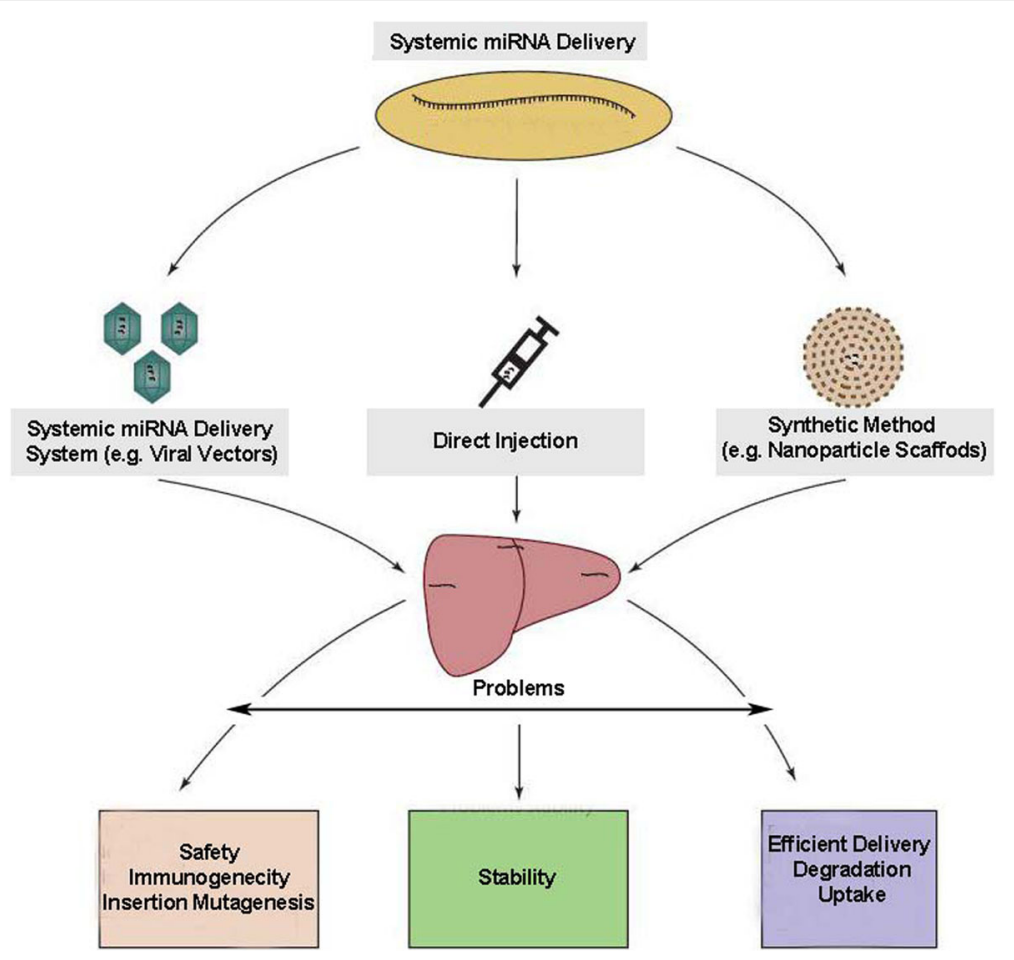

Fig. 2 miRNA delivery systems in the field of tissue engineering

potent ability in reciprocal communication, exosomes could maintain steady-state crosstalk between different cells by using autocrine, paracrine and juxtacrine pathways. The active role of exosomes was previously proved on blood vessels development and progression [91]. Recent evidence suggests the existence of specific miRNAs inside exosomes with the angiogenic potential in the target cells by the induction of VEGF and different signaling pathways [92, 93]. In contrast, exosomes could harbor some miRNAs with anti-angiogenesis properties [94] (Table 5). It was revealed that the conjugation of exosomes with tricalcium phosphate scaffolds promoted osteogenic differentiation of bone marrow MSCs through the activation of PI3K/Akt signaling axis [95]. By increasing the concentration of transplanted exosomes in tricalcium phosphate-based scaffolds, there was a profound bone formation and angiogenesis rate in the rat model of bone defects [96]. These features indicated the potential of exosomes as bio-shuttles in modulating the vascularization rate after being loaded on distinct scaffolds.

\section{Synthetic methods}

Non-viral-based approaches for genetic material delivery have attracted the attention of a bulk of authorities over the last decades. In the late 1990s, the term geneactivated matrixes emerged and the first report documented collagen-based scaffolds used to deliver galactosidase-based pDNA for the acceleration of bone formation. At the present time, numerous synthetic delivery systems are used with miRNAs as follows;

(a) lipid-based; (b) polyethyleneimine (PEI)-based; (c) dendrimer-based; (d) poly (a-hydroxy acid) polymers (in nano-particle or scaffold form); (e) fabrication of biopolymers as particles such as chitosan and protamine, atelocollagen, and protein translocation domain-derived peptides or scaffolds, (f) inorganic nanoparticles (gold, silica-based, or magnetic) and scaffolds. In the majority

Table 5 The existence of various miRNAs with pro- and antiangiogenesis capacity

\begin{tabular}{lll}
\hline miRNA & Function & Ref \\
\hline miRNA-17-92 & $\begin{array}{l}\text { Promotes angiogenesis by modulation } \\
\text { of connective tissue growth factor, } \\
\text { thrombospondin-1, and integrin a5 }\end{array}$ & [159] \\
&
\end{tabular}

miRNA-92a Has a dual pro- and anti-angiogenic role [160]

miRNA-21 Increases VEGF level and promotes [161] angiogenesis through a STAT3dependent mechanism

miRNA-494 Suppresses PTEN and activates Akt/eNOS [162]

miR-135b in Reduces the expression of FlH-1 and [163] exosomes from hypoxic multiple myeloma cells

miR-125a Promotes angiogenesis by inhibiting DLL-4 
of methods, the synthesis is governed by self-assembling of synthetic materials such as lipids (liposomes), unprocessed polymers (dendrimers), or functionalized polymers with active sites. Indeed, it is such self-assembled nature that offers considerable superiorities over viralbased methods with potential for controlling molecular composition, targeted ligand-receptor attachment, tolerance of large (multiple plasmids) cargo sizes, disassembly and release of payloads, simplified manufacturing, modification, scale up, ease of analysis and quality control, and low immunogenicity rate [97]. These synthetic systems possess similar efficacy to viral-based methods in vitro. The use of synthetic systems in in vivo condition is increasing as well; however, challenges remain in terms of efficacy via intravenous versus local injection, sufficient delivery of miRNAs to the site of injury without degradation or nonspecific binding, appropriate uptake by the appropriate cell type within complex tissues, and, thereafter, persistence of gene expression or inhibition in favor of regeneration $[98,99]$. Non-viral carriers seem to be more effective compared to viral counterparts, however, the lack of specificity to target sites and uncontrolled bio-distribution limit the use of non-viral approaches.

\section{Growth factor incorporation into scaffolds}

Various growth factors could concurrently be combined with scaffolds to facilitate regeneration rate. In general, scaffolds-coated with growth factors could promote the introduction of these molecules to target sites, expending the rate of recovery. Due to an inherent kinetics and different features controlling the release of growth factors, the more fundamental experiments are needed to address underlying mechanisms. Of note, the protein structure and function must not be changed during the procedure. VEGF is a peptide growth factor that recently coated on the PLA-based scaffold for controlling angiogenic signals [100]. The sustained release and active dynamic of VEGF were confirmed by several techniques in vitro in HUVEC assay and in vivo condition such as chick allantoic membrane. It was showed that VEGF has a unique role for vascularization in PLA-based scaffolds. Different growth factors can be loaded to the surface of scaffolds via interaction with chemical groups of drug and proteins. In support of this idea, such scaffolds are synthesized to mimic in vivo microenvironment with the ability of growth and differentiation for human SCs. Prior to enrollment in tissue engineering procedures, the function of transplants can be improved by using multiple growth factors with different formulas, offering a wonderful way to control tissue regeneration. However, the release of specific protein must be elucidated on distinct tissues to specific cells in the context of target tissue [101]. In spite of an enhanced angiogenesis rate induced by the mixture of scaffolds-growth factors, normal kinetics and appropriate sustained release of each factor must be calculated in in vivo condition.

\section{Effect of biomaterials on the intracellular angiogenesis signaling pathway}

It is believed that the changes in the physicochemical and morphological properties of cells on different scaffolds could modulate the angiogenesis potential [102] (Fig. 3). The mutual crosstalk between cells and surrounding scaffolds via adhesive molecules such as laminin, fibronectin, vitronectin, tenascin, and hydrophilic proteoglycans can initiate specific signaling, termed as external transduction [103]. On the other hand, the cell could attach to surfaces by expressing integrins, immunoglobulin superfamily, cadherins, selectins, and other adhesive molecules [104]. Using juxtacrine interaction of cell receptors with cognate motifs in scaffolds, a plethora of intracellular biochemical reactions would be ignited, resulting in the modulation of cells phenotype, motility and migration, dynamic cell growth and genes expression profile. In addition to the maintenance of cell-matrix interaction, it seems that the cell-to-cell connection is improved as well [105].

The juxtaposition of each cell with scaffold chemical groups is done through the activation of surface mechanoreceptors and thereby a reciprocal bridge is formed. This attachment provokes contractile cytoskeletal agents with the collaboration of focal adhesion complexes [106]. The cytoskeletal adaptation was reported in ECs cultured in a denaturated collagen matrix by re-arranging actin filament and distribution of focal adhesion proteins such as Src-dependent signaling pathway [107].

The scaffold enriched by beta-tricalcium phosphate has been found to promoted angiogenesis in HUVECs by engaging the PI3K/Akt/eNOS axis [108]. In addition to the chemical composition of scaffolds, the 3D alignment and microstructure could stimulate and/or inhibit the normal dynamic of cells. By adding fibrin to collagenbased scaffolds, the basal metabolic activity of cells showed to be altered which was evident by an enhanced proliferation rate. The migration of enclosed cells was increased by the induction of MMP-2 and -9 [109]. It was shown that fibrin could attach to cell surface integrin $\alpha_{v} \beta_{3}$ and improve the interaction of circulating leukocytes with ECs via the modulation of VE-cadherin [110]. The promotion of cell recruitment and orientated differentiation could yield in better regeneration capacity [111]. Matthew and colleagues previously stated that the enrichment of collagen scaffold with HA had a prominent effect on the cell recruitment and differentiation into endothelial and osteoblast lineages [112]. Previously, the positive effect of HA was indicated on the dynamic of angiogenesis mediated by CD44 and 


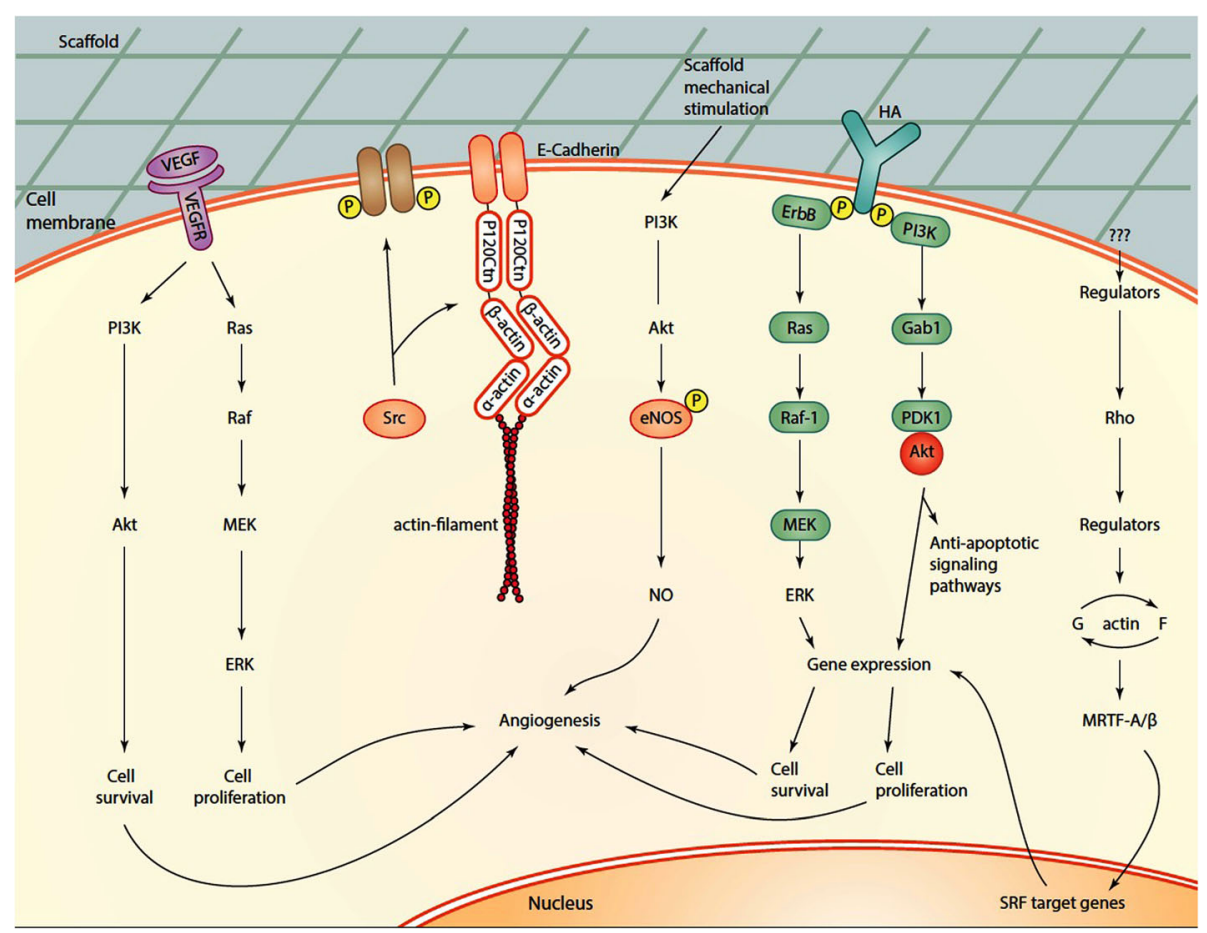

Fig. 3 Effect of different of biomaterials on intracellular angiogenesis signaling pathways. VEGFR-2, E-cadherin and CD44 could be initiated after juxtaposition to different scaffolds. Signaling pathways effectors such as Akt and Raf and Erk are stimulated during angiogenesis potential. HA: Hyaluronic acid

protein kinase $C(\delta)$. Fibrin was also found to activate plasminogen activator-inhibitor-1, TGF- $\beta$ receptor I and Erk [113]. Experiments revealed that the intra-fibrillar silicified collagen forced monocytes to secret SDF- $1 \alpha$, TGF- $\beta 1$, VEGFA, and PDGF-BB which are a key regulator in the initiation of angiogenesis [114]. Addition of ionized calcium with PLA and on bioactive glass G5 promoted angiogenesis by stimulating factors GATA2, TFII-I, and NF-кB. The expression of VEGFR-2, as a tyrosine kinase-related receptors, was also induced as well [115]. The use of suitable scaffolds with appropriate physicochemical stability and combination with various factors and ECM components could re-organize cells alignment in the favor of vascularization and engineered vascular grafts.

\section{Conclusions and future perspectives}

In accordance with a great body of previous studies and what is highlighted in the current review article, angiogenesis is the main target and reliable mean to increase the efficiency of tissue regeneration by cell transplantation, gene therapy, and factor release. Based on target tissues, inherent advantages and limitations of each delivery method must be considered. Choosing distinct cell type, selection of scaffolds and carriers fabricated by different biomaterials, and orientation of cells to vascular cells using growth factors and genetic manipulation seem pivotal to accelerate the vascularization rate. It seems that different scaffolds could influence the rate of angiogenesis via regulating cell morphology and alignment inside the matrices. Calculation of appropriate initial cell number for transplantation, route of administration (either local or systemic), contents and growth factor formulation along with transient and/or permanent genetic modification are also important. In some cases, cell-free strategies could also eliminate the need for simultaneous application of cells with growth factors. As a matter of fact, application and invention of novel strategies with the capability to preserve factors for long periods with a sustained release activity must be at the center of attention. Exosomes, as cell byproducts encompassing a large number of factors, having a high stability could be introduced as angiogenic bio-shuttles with various scaffolds without any unpredictable complications. In addition to the composition and structure of scaffolds, the bioavailability, biodegradability, and route of administration must be detected related to distinct tissue type.

\section{Abbreviations}

AAV: Adeno-associated virus; AMO: anti-miRNA oligonucleotide; Ang2: Angiopoietin-2; bFGF: Basic fibroblast growth factor; CECs: Circulating endothelial cells; CECs: Circulating endothelial cells; DDL-4: Delta ligand 4; ECM: Extracellular matrix; EPCs: Endothelial progenitor cells; FIH-1: Factor inhibiting HIF-1; HA: Hyaluronic acid; HSCs: Hematopoietic stem cells; HUVECs: Human umbilical vein endothelial cells; iPSCs: Induced pluripotent 
stem cells; miRISC: miRNA-induced-silencing-complex; miRNA: microRNA; MMP-2 and -9: Matrix metalloproteinase-2 and -9; MSCs: Mesenchymal stem cells; PDGF-BB: Platelet-derived growth factor; PECAM: Platelet endothelial cell adhesion molecule; PEI: Polyethylenimine; PLA: Poly(lactic acid); SCs: Adult stem cells; SDF-1a: Stromal cell-derived factor 1; SMC: Structural maintenance of chromosomes; STAT3: Signal transducer and activator of transcription 3; TGF- $\beta$ receptor I: Transforming growth factor $\beta$ receptor I; VE-cadherin: Vascular endothelial cadherin: VEGF: Vascular endothelial growth factor; VEGFR2: Vascular endothelial growth factor receptor 2; a-SMCs: alpha smooth muscle cells

\section{Acknowledgments}

Authors wish to thank the personnel of Stem Cell Research Center for kindest collaboration.

\section{Funding}

This review article is supported by a grant from Tabriz University of Medical Sciences.

\section{Availability of data and materials}

Not applicable.

\section{Authors' contributions}

SS: Data collection and manuscript writing; MHG and $\mathrm{M} \mathrm{H}$ manuscript writing and figure preparation; $\mathrm{HH}$ : Equal conceptualization; R R and MN: Equal conceptualization and manuscript edition. All authors read and approved the final manuscript.

\section{Ethics approval and consent to participate}

Not applicable.

\section{Consent for publication}

Not applicable.

\section{Competing interests}

The authors declare that they have no competing interests.

\section{Publisher's Note}

Springer Nature remains neutral with regard to jurisdictional claims in published maps and institutional affiliations.

\section{Author details}

'Stem Cell Research Center, Tabriz University of Medical Sciences, Imam Reza St., Golgasht St, Tabriz 5166614756, Iran. ${ }^{2}$ Department of Molecular Medicine, Faculty of Advanced Medical Sciences, Tabriz University of Medical Sciences, Tabriz, Iran. ${ }^{3}$ Neuroscience Research Center, Imam Reza Medical Center, Tabriz University of Medical Sciences, Tabriz, Iran. ${ }^{4}$ Innovation Center for Advanced Technology, Matrix, Inc., New York, NY 10029, USA. ${ }^{5}$ Department of Applied Cell Sciences, Faculty of Advanced Medical Sciences, Tabriz University of Medical Sciences, Tabriz, Iran.

Received: 10 October 2018 Accepted: 13 December 2018

Published online: 27 December 2018

\section{References}

1. Rana D, Zreiqat H, Benkirane-Jessel N, Ramakrishna S, Ramalingam M. Development of decellularized scaffolds for stem cell-driven tissue engineering. J Tissue Eng Regen Med. 2017;11(4):942-65.

2. Cosson S, Otte EA, Hezaveh H, Cooper-White JJ. Concise review: tailoring bioengineered scaffolds for stem cell applications in tissue engineering and regenerative medicine. Stem Cells Transl Med. 2015;4(2):156-64.

3. Rezaie J, Mehranjani MS, Rahbarghazi R, Shariatzadeh MA. Angiogenic and Restorative Abilities of Human Mesenchymal Stem Cells Were Reduced Following Treatment With Serum From Diabetes Mellitus Type 2 Patients. J Cell Biochem. 2018;119(1):524-35. https://doi.org/10.1002/jcb.26211.

4. Hassanpour M, Cheraghi O, Siavashi V, Rahbarghazi R, Nouri M. A reversal of age-dependent proliferative capacity of endothelial progenitor cells from different species origin in in vitro condition. J Cardiovasc Thor Res. 2016: 8(3):102-6. https://doi.org/10.15171/jcvtr.2016.22.
5. Mueller $\mathrm{SB}$, Kontos $\mathrm{CD}$. Tie1: an orphan receptor provides context for angiopoietin-2/Tie2 signaling. J Clin Invest. 2016;126(9):3188-91. https://doi. org/10.1172/jci89963.

6. Song $H$, Cheng $Y, B i G$, Zhu $Y$, Jun $W$, Ma W, et al. Release of matrix Metalloproteinases-2 and 9 by S-Nitrosylated Caveolin-1 contributes to degradation of extracellular matrix in tPA-treated hypoxic endothelial cells. PLoS One. 2016;1 1(2):e0149269. https://doi.org/10.1371/journal. pone.0149269.

7. Rohlenova K, Veys K, Miranda-Santos I, De Bock K, Carmeliet P. Endothelial cell metabolism in health and. Trends Cell Biol. 2018;28(3):225.

8. Díaz-Flores L, Gutiérrez R, González-Gómez M, García P, Sáez FJ, Díaz-Flores $L \mathrm{Jr}$, et al. Segmentation of dilated Hemorrhoidal veins in Hemorrhoidal disease. Cells Tissues Organs. 2018;205:1-9.

9. Paku S, Dezső K, Bugyik E, Tóvári J, Tímár J, Nagy P, et al. A new mechanism for pillar formation during tumor-induced intussusceptive angiogenesis: inverse sprouting. Am J Pathol. 2011;179(3):1573-85. https://doi.org/10.1016/ j.ajpath.2011.05.033.

10. Lancerotto L, Orgill DP. Mechanoregulation of angiogenesis in wound healing. Adv Wound Care. 2014;3(10):626-34.

11. Kumar G, Narayan B. The biology of fracture healing in long bones. Classic Papers in Orthopaedics. Springer; 2014. p. 531-533.

12. Madeddu P. Therapeutic angiogenesis and vasculogenesis for tissue regeneration. Exp Physiol. 2005;90(3):315-26.

13. Bjelakovic MD, Vlajkovic S, Petrovic A, Bjelakovic M, Antic M. Stereological study of developing glomerular forms during human fetal kidney development. Pediatr Nephrol. 2017:1-9.

14. Selvam S, Kumar T, Fruttiger M. Retinal vasculature development in health and disease. Prog Retin Eye Res. 2017.

15. D'Angelo L, Myer NM, Myers KA. MCAK-mediated regulation of endothelial cell microtubule dynamics is mechanosensitive to myosin-ll contractility. Mol Biol Cell. 2017;28(9):1223-37.

16. Du P, Suhaeri M, Ha SS, Oh SJ, Kim S-H, Park K. Human lung fibroblastderived matrix facilitates vascular morphogenesis in $3 D$ environment and enhances skin wound healing. Acta Biomater. 2017;54:333-44.

17. Frismantiene A, Philippova M, Erne P, Resink TJ. Cadherins in vascular smooth muscle cell (patho) biology: quid nos scimus? Cell Signal. 2018:45:23-42.

18. Cheresh D, Stupack D. Regulation of angiogenesis: apoptotic cues from the ECM. Oncogene. 2008;27(48):6285-98.

19. Hoenig MR, Campbell GR, Rolfe BE, Campbell JH. Tissue-engineered blood vessels: alternative to autologous grafts? Arterioscler Thromb Vasc Biol. 2005; 25(6):1128-34.

20. Dean EW, Udelsman B, Breuer CK. Current advances in the translation of vascular tissue engineering to the treatment of pediatric congenital heart disease. Yale J Biol Med. 2012;85(2):229

21. Dahl SL, Kypson AP, Lawson JH, Blum JL, Strader JT, Li Y, et al. Readily available tissue-engineered vascular grafts. Sci Transl Med. 2011;3(68): 68ra9-9.

22. Nemeno-Guanzon JG, Lee S, Berg JR, Jo YH, Yeo JE, Nam BM, et al. Trends in tissue engineering for blood vessels. Biomed Res Int. 2012;2012.

23. Carmeliet P, Jain RK. Molecular mechanisms and clinical applications of angiogenesis. Nature. 2011;473(7347):298.

24. Jung YJ, Kim K-C, Heo J-Y, Jing K, Lee KE, Hwang JS, et al. Induction of angiogenesis by matrigel coating of VEGF-loaded PEG/PCL-based hydrogel scaffolds for hbmsc transplantation. Mol Cells. 2015;38(7):663.

25. Sun X, Altalhi W, Nunes SS. Vascularization strategies of engineered tissues and their application in cardiac regeneration. Adv Drug Deliv Rev. 2016; 96:183-94.

26. Zureikat AH, Nguyen T, Boone BA, Wijkstrom M, Hogg ME, Humar A, et al. Robotic total pancreatectomy with or without autologous islet cell transplantation: replication of an open technique through a minimal access approach. Surg Endosc. 2015;29(1):176-83.

27. Ong CS, Zhou X, Huang CY, Fukunishi T, Zhang H, Hibino N. Tissue engineered vascular grafts: current state of the field. Expert Rev Med Devices. 2017;14(5):383-92.

28. Pinho SS, Reis CA. Glycosylation in cancer: mechanisms and clinical implications. Nat Rev Cancer. 2015;15(9):540.

29. Khademhosseini A, Langer R. A decade of progress in tissue engineering. Nat Protoc. 2016;11(10):1775

30. Serbo JV, Gerecht S. Vascular tissue engineering: biodegradable scaffold platforms to promote angiogenesis. Stem Cell Res Ther. 2013;4(1):8. 
31. Ingram DA, Mead LE, Tanaka H, Meade V, Fenoglio A, Mortell K, et al. Identification of a novel hierarchy of endothelial progenitor cells using human peripheral and umbilical cord blood. Blood. 2004;104(9):2752-60.

32. Traktuev DO, Merfeld-Clauss S, Li J, Kolonin M, Arap W, Pasqualini R, et al. A population of multipotent CD34-positive adipose stromal cells share pericyte and mesenchymal surface markers, reside in a periendothelial location, and stabilize endothelial networks. Circ Res. 2008;102(1):77-85.

33. Tang F, Barbacioru C, Bao S, Lee C, Nordman E, Wang X, et al. Tracing the derivation of embryonic stem cells from the inner cell mass by single-cell RNA-Seq analysis. Cell Stem Cell. 2010;6(5):468-78.

34. Paoletti C, Divieto C, Chiono V. Impact of biomaterials on differentiation and reprogramming approaches for the generation of functional cardiomyocytes. Cell. 2018;7(9):114. https://doi.org/10.3390/cells7090114.

35. Lu S-J, Ivanova Y, Feng Q, Luo C, Lanza R. Hemangioblasts from human embryonic stem cells generate multilayered blood vessels with functional smooth muscle cells; 2009.

36. Le Belle JE, Orozco NM, Paucar AA, Saxe JP, Mottahedeh J, Pyle AD, et al. Proliferative neural stem cells have high endogenous ROS levels that regulate self-renewal and neurogenesis in a PI3KJAkt-dependant manner. Cell Stem Cell. 2011;8(1):59-71.

37. Zhang P, Moudgill N, Hager E, Tarola N, DiMatteo C, Mcllhenny S, et al. Endothelial differentiation of adipose-derived stem cells from elderly patients with cardiovascular disease. Stem Cells Dev. 2010;20(6):977-88.

38. Mauritz C, Schwanke K, Reppel M, Neef S, Katsirntaki K, Maier LS, et al. Generation of functional murine cardiac myocytes from induced pluripotent stem cells. Circulation. 2008;118(5):507-17.

39. Tateishi K, Takehara N, Matsubara H, Oh H. Stemming heart failure with cardiac-or reprogrammed-stem cells. J Cell Mol Med. 2008;12(6a):2217-32.

40. Stadtler $\mathrm{H}$. Supply chain management: An overview. Supply chain management and advanced planning. Springer; 2015. p. 3-28.

41. Lee A-Y, Lee J, Kim C-L, Lee KS, Lee S-H, Gu N-Y, et al. Comparative studies on proliferation, molecular markers and differentiation potential of mesenchymal stem cells from various tissues (adipose, bone marrow, ear skin, abdominal skin, and lung) and maintenance of multipotency during serial passages in miniature pig. Res Vet Sci. 2015;100:115-24.

42. Richard A, Boullu L, Herbach U, Bonnafoux A, Morin V, Vallin E, et al. Singlecell-based analysis highlights a surge in cell-to-cell molecular variability preceding irreversible commitment in a differentiation process. PLOS Biol. 2016;14(12):e1002585.

43. Kajstura J, Urbanek K, Rota M, Bearzi C, Hosoda T, Bolli R, et al. Cardiac stem cells and myocardial disease. J Mol Cell Cardiol. 2008;45(4):505-13.

44. Masuda S, Shimizu T. Three-dimensional cardiac tissue fabrication based on cell sheet technology. Adv Drug Deliv Rev. 2016;96:103-9.

45. Roura S, Soler-Botija C, Bagó JR, Llucià-Valldeperas A, Férnandez MA, GálvezMontón C, et al. Postinfarction functional recovery driven by a threedimensional engineered fibrin patch composed of human umbilical cord blood-derived mesenchymal stem cells. Stem Cells Transl Med. 2015;4(8): 956-66

46. Avior Y, Sagi I, Benvenisty N. Pluripotent stem cells in disease modelling and drug discovery. Nat Rev Mol Cell Biol. 2016;17(3):170.

47. Singh KP, Sharma AM. Critical limb ischemia: current approach and future directions. J Cardiovasc Transl Res. 2014;7(4):437-45.

48. Gonzales-Portillo GS, Sanberg PR, Franzblau M, Gonzales-Portillo C, Diamandis T, Staples M, et al. Mannitol-enhanced delivery of stem cells and their growth factors across the blood-brain barrier. Cell Transplant. 2014; 23(4-5):531-9.

49. Zhang WJ, Liu W, Cui L, Cao Y. Tissue engineering of blood vessel. J Cell Mol Med. 2007;11(5):945-57.

50. Singh S, Wu BM, Dunn JC. The enhancement of VEGF-mediated angiogenesis by polycaprolactone scaffolds with surface cross-linked heparin. Biomaterials. 2011;32(8):2059-69.

51. Hussain A, Cahalan P, Cahalan L. Methods of making bioactive collagen medical scaffolds such as for wound care dressings, hernia repair prosthetics, and surgical incision closure members. Google Patents; 2017.

52. Singelyn JM, DeQuach JA, Seif-Naraghi SB, Littlefield RB, Schup-Magoffin PJ, Christman KL. Naturally derived myocardial matrix as an injectable scaffold for cardiac tissue engineering. Biomaterials. 2009;30(29):5409-16.

53. Mima Y, Fukumoto S, Koyama H, Okada M, Tanaka S, Shoji T, et al. Enhancement of cell-based therapeutic angiogenesis using a novel type of injectable scaffolds of hydroxyapatite-polymer nanocomposite microspheres. PLoS One. 2012;7(4):e35199.
54. Lee TC, Niederer P. Basic engineering for medics and biologists: an ESEM primer: IOS Press; 2010.

55. Lyons FG, Al-Munajjed AA, Kieran SM, Toner ME, Murphy CM, Duffy GP, et al The healing of bony defects by cell-free collagen-based scaffolds compared to stem cell-seeded tissue engineered constructs. Biomaterials. 2010;31(35): 9232-43.

56. DiMuzio $P$, Tulenko T. Tissue engineering applications to vascular bypass graft development: the use of adipose-derived stem cells. J Vasc Surg. 2007; 45(6):A99-A103.

57. Lee SJ, Liu J, Oh SH, Soker S, Atala A, Yoo JJ. Development of a composite vascular scaffolding system that withstands physiological vascular conditions. Biomaterials. 2008;29(19):2891-8.

58. Chan B, Leong K. Scaffolding in tissue engineering: general approaches and tissue-specific considerations. Eur Spine J. 2008;17(4):467-79.

59. Pektok E, Nottelet B, Tille J-C, Gurny R, Kalangos A, Moeller M, et al. Degradation and healing characteristics of small-diameter poly $(\varepsilon-$ caprolactone) vascular grafts in the rat systemic arterial circulation. Circulation. 2008;118(24):2563-70.

60. Rocco KA, Maxfield MW, Best CA, Dean EW, Breuer CK. In vivo applications of electrospun tissue-engineered vascular grafts: a review. Tissue Eng B Rev. 2014:20(6):628-40.

61. Daley WP, Peters SB, Larsen M. Extracellular matrix dynamics in development and regenerative medicine. J Cell Sci. 2008;121(3):255-64.

62. Hutmacher DW, Schantz JT, Lam CXF, Tan KC, Lim TC. State of the art and future directions of scaffold-based bone engineering from a biomaterials perspective. J Tissue Eng Regen Med. 2007;1(4):245-60.

63. Ma Z, Mao Z, Gao C. Surface modification and property analysis of biomedical polymers used for tissue engineering. Colloids Surf B: Biointerfaces. 2007;60(2):137-57.

64. Calabrese G, Giuffrida R, Fabbi C, Figallo E, Furno DL, Gulino R, et al. Collagen-hydroxyapatite scaffolds induce human adipose derived stem cells osteogenic differentiation in vitro. PLoS One. 2016;11(3):e0151181.

65. MJPd S. Development of paper-based devices, using a simple phase separation process for the fabrication of biomimetic superhydrophobic paper substrates; 2012

66. McKenna KA, Hinds MT, Sarao RC, Wu P-C, Maslen CL, Glanville RW, et al. Mechanical property characterization of electrospun recombinant human tropoelastin for vascular graft biomaterials. Acta Biomater. 2012;8(1):225-33.

67. Aper T, Schmidt A, Duchrow M, Bruch H-P. Autologous blood vessels engineered from peripheral blood sample. Eur J Vasc Endovasc Surg. 2007; 33(1):33-9.

68. Rowe SL, Lee S, Stegemann JP. Influence of thrombin concentration on the mechanical and morphological properties of cell-seeded fibrin hydrogels. Acta Biomater. 2007;3(1):59-67.

69. Ye Q, Zünd G, Benedikt P, Jockenhoevel S, Hoerstrup SP, Sakyama S, et al. Fibrin gel as a three dimensional matrix in cardiovascular tissue engineering. Eur J Cardiothorac Surg. 2000;17(5):587-91.

70. Neidert M, Lee E, Oegema T, Tranquillo R. Enhanced fibrin remodeling in vitro with TGF- $\beta 1$, insulin and plasmin for improved tissue-equivalents. Biomaterials. 2002;23(17):3717-31

71. Tam SK, Dusseault J, Polizu S, Ménard M, Hallé J-P, Yahia LH. Physicochemical model of alginate-poly-l-lysine microcapsules defined at the micrometric/nanometric scale using ATR-FTIR, XPS, and ToF-SIMS. Biomaterials. 2005;26(34):6950-61.

72. Salgado $\mathrm{CL}$, Oliveira MB, Mano JF. Combinatorial cell-3D biomaterials cytocompatibility screening for tissue engineering using bioinspired superhydrophobic substrates. Integr Biol. 2012;4(3):318-27.

73. Oliveira MB, Ribeiro MP, Miguel SP, Neto Al, Coutinho P, Correia IJ, et al. In vivo high-content evaluation of three-dimensional scaffolds biocompatibility. Tissue Eng Part C Methods. 2014;20(11):851-64.

74. Yu J, Gu Y, Du KT, Mihardja S, Sievers RE, Lee RJ. The effect of injected RGD modified alginate on angiogenesis and left ventricular function in a chronic rat infarct model. Biomaterials. 2009;30(5):751-6.

75. Puga AM, Lima AC, Mano JF, Concheiro A, Alvarez-Lorenzo C. Pectin-coated chitosan microgels crosslinked on superhydrophobic surfaces for 5 fluorouracil encapsulation. Carbohydr Polym. 2013;98(1):331-40.

76. Ameres SL, Horwich MD, Hung J-H, Xu J, Ghildiyal M, Weng Z, et al. Target RNA-directed trimming and tailing of small silencing RNAs. Science. 2010; 328(5985):1534-9

77. Lennox KA, Behlke MA. A direct comparison of anti-microRNA oligonucleotide potency. Pharm Res. 2010;27(9):1788-99. 
78. Bader A, Brown D, Stoudemire J, Lammers P. Developing therapeutic microRNAs for cancer. Gene Ther. 2011;18(12):1121-6.

79. Khalil IA, Kogure K, Akita H, Harashima H. Uptake pathways and subsequent intracellular trafficking in nonviral gene delivery. Pharmacol Rev. 2006; 58(1):32-45.

80. Zhang Y, Wang Z, Gemeinhart RA. Progress in microRNA delivery. J Control Release. 2013;172(3):962-74.

81. Ruberti F, Barbato C, Cogoni C. Targeting microRNAs in neurons: tools and perspectives. Exp Neurol. 2012;235(2):419-26.

82. Fabani MM, Abreu-Goodger C, Williams D, Lyons PA, Torres AG, Smith KG, et al. Efficient inhibition of miR-155 function in vivo by peptide nucleic acids. Nucleic Acids Res. 2010;38(13):4466-75.

83. Li Y, Fan L, Liu S, Liu W, Zhang H, Zhou T, et al. The promotion of bone regeneration through positive regulation of angiogenic-osteogenic coupling using microRNA-26a. Biomaterials. 2013;34(21):5048-58.

84. Shang J, Liu H, Zhou Y. Roles of microRNAs in prenatal chondrogenesis, postnatal chondrogenesis and cartilage-related diseases. J Cell Mol Med. 2013;17(12):1515-24

85. Yang B, Guo H, Zhang Y, Chen L, Ying D, Dong S. MicroRNA-145 regulates chondrogenic differentiation of mesenchymal stem cells by targeting Sox9. PLoS One. 2011;6(7):e21679.

86. van Rooij E, Purcell AL, Levin AA. Developing microRNA therapeutics. Circ Res. 2012;110(3):496-507.

87. Liu YP, Berkhout B. miRNA cassettes in viral vectors: problems and solutions. Biochimica et Biophysica Acta (BBA)-Gene Regulatory Mechanisms. 2011; 1809(11):732-45.

88. Elmén J, Lindow M, Schütz S, Lawrence M, Petri A, Obad S, et al. LNAmediated microRNA silencing in non-human primates. Nature. 2008; 452(7189):896-9.

89. Hullinger TG, Montgomery RL, Seto AG, Dickinson BA, Semus HM, Lynch JM, et al. Inhibition of miR-15 protects against cardiac ischemic InjuryNovelty and significance. Circ Res. 2012;110(1):71-81.

90. Bjørge IM, Kim SY, Mano J, Kalionis B, Chrzanowski W. Extracellular vesicles, exosomes and shedding vesicles in regenerative medicine-a new paradigm for tissue repair. Biomaterials science. 2018;6(1):60-78.

91. Ludwig N, Yerneni SS, Razzo BM, Whiteside TL. Exosomes from HNSCC promote angiogenesis through reprogramming of endothelial cells. Mol Cancer Res. 2018;16(11):1798-808.

92. Liang X, Zhang L, Wang S, Han Q, Zhao RC. Exosomes secreted by mesenchymal stem cells promote endothelial cell angiogenesis by transferring miR-125a. J Cell Sci. 2016;129(11):2182-9.

93. Ohyashiki JH, Umezu T, Ohyashiki K. Exosomes promote bone marrow angiogenesis in hematologic neoplasia: the role of hypoxia. Curr Opin Hematol. 2016;23(3):268-73.

94. Ribeiro MF, Zhu H, Millard RW, Fan G-C. Exosomes function in pro- and anti-angiogenesis. Current angiogenesis. 2013;2(1):54-9. https://doi.org/ $10.2174 / 22115528113020020001$

95. Zhang J, Liu X, Li H, Chen C, Hu B, Niu X et al. Exosomes/tricalcium phosphate combination scaffolds can enhance bone regeneration by activating the PI3K/Akt signaling pathway. Stem cell research \& therapy. 2016;7(1):136-. doi:https://doi.org/10.1186/s13287-016-0391-3.

96. Qi X, Zhang J, Yuan H, Xu Z, Li Q, Niu X, et al. Exosomes secreted by human-induced pluripotent stem cell-derived mesenchymal stem cells repair critical-sized bone defects through enhanced angiogenesis and osteogenesis in osteoporotic rats. Int J Biol Sci. 2016;12(7):836-49. https://doi.org/10.7150/ijbs.14809.

97. Juliano RL, Ming X, Nakagawa O. Cellular uptake and intracellular trafficking of antisense and siRNA oligonucleotides. Bioconjug Chem. 2011;23(2):147-57.

98. Suh JS, Lee JY, Choi YS, Chong PC, Park YJ. Peptide-mediated intracellular delivery of miRNA-29b for osteogenic stem cell differentiation. Biomaterials. 2013:34(17):4347-59

99. Wu K, Song W, Zhao L, Liu M, Yan J, Andersen M $\varnothing$, et al. MicroRNA functionalized microporous titanium oxide surface by lyophilization with enhanced osteogenic activity. ACS Appl Mater Interfaces. 2013;5(7):2733-44.

100. Simón-Yarza T, Formiga FR, Tamayo E, Pelacho B, Prosper F, Blanco-Prieto MJ. Vascular endothelial growth factor-delivery systems for cardiac repair: an overview. Theranostics. 2012;2(6):541.

101. Heyde M, Partridge KA, Howdle SM, Oreffo RO, Garnett MC, Shakesheff KM Development of a slow non-viral DNA release system from PDLLA scaffolds fabricated using a supercritical CO2 technique. Biotechnol Bioeng. 2007; 98(3):679-93.
102. Subramani B, Subbannagounder S, Palanivel S, Ramanathanpullai C, Sivalingam S, Yakub A, et al. Generation and characterization of human cardiac resident and non-resident mesenchymal stem cell. Cytotechnology. 2016;68(5):2061-73.

103. Hallmann R, Zhang X, Di Russo J, Li L, Song J, Hannocks M-J, et al. The regulation of immune cell trafficking by the extracellular matrix. Curr Opin Cell Biol. 2015;36:54-61.

104. Friedl P, Mayor R. Tuning collective cell migration by cell-cell junction regulation. Cold Spring Harb Perspect Biol. 2017;9(4):a029199.

105. Alcover A, Alarcón B, Di Bartolo V. Cell biology of T cell receptor expression and regulation. Annu Rev Immunol 2017(0).

106. Siton-Mendelson O, Bernheim-Groswasser A. Functional actin networks under construction: the cooperative action of actin nucleation and elongation factors. Trends Biochem Sci. 2017;42(6):414-30.

107. Mui KL, Chen CS, Assoian RK. The mechanical regulation of integrincadherin crosstalk organizes cells, signaling and forces. J Cell Sci. 2016; 129(6):1093-100.

108. Zhang Y, Lei Z, Qi Y, Di T, Li G, Zhang W, et al. Adipose-derived stem cell sheet encapsulated construct of micro-porous decellularized cartilage debris and hydrogel for cartilage defect repair. Med Hypotheses. 2017;109:111-3.

109. Jansen $P L$, Rosch $R$, Jansen M, Binnebösel M, Junge K, Alfonso-Jaume A, et al. Regulation of MMP-2 gene transcription in dermal wounds. J Investig Dermatol. 2007;127(7):1762-7.

110. Reymond N, d'Água BB, Ridley AJ. Crossing the endothelial barrier during metastasis. Nat Rev Cancer. 2013;13(12):858.

111. Kitamura T, Qian B-Z, Pollard JW. Immune cell promotion of metastasis. Nat Rev Immunol. 2015:15(2):73.

112. Grellier M, Bordenave L, Amedee J. Cell-to-cell communication between osteogenic and endothelial lineages: implications for tissue engineering. Trends Biotechnol. 2009;27(10):562-71.

113. Chen G, Deng C, Li Y-P. TGF- $\beta$ and BMP signaling in osteoblast differentiation and bone formation. Int J Biol Sci. 2012;8(2):272.

114. Li B, Xiu R. Angiogenesis: from molecular mechanisms to translational implications. Clin Hemorheol Microcirc. 2013;54(4):345-55.

115. Aguirre A, González A, Navarro M, Castaño Linares Ó, Planell Estany JA, Engel LE. Control of microenvironmental cues with a smart biomaterial composite promotes endothelial progenitor cell angiogenesis. European cells and materials. 2012;24:90-106.

116. Bach F, Albertini R, Joo P, Anderson J, Bortin M. Bone-marrow transplantation in a patient with the Wiskott-Aldrich syndrome. Lancet. 1968;292(7583):1364-6.

117. Saporta S, Kim J-J, Willing AE, Fu ES, Davis CD, Sanberg PR. Human umbilical cord blood stem cells infusion in spinal cord injury: engraftment and beneficial influence on behavior. J Hematother Stem Cell Res. 2003;12(3):271-8

118. De Coppi P, Bartsch G Jr, Siddiqui MM, Xu T, Santos CC, Perin L, et al. Isolation of amniotic stem cell lines with potential for therapy. Nat Biotechnol. 2007:25(1):100.

119. Uygun BE, Soto-Gutierrez A, Yagi H, Izamis M-L, Guzzardi MA, Shulman C, et al. Organ reengineering through development of a transplantable recellularized liver graft using decellularized liver matrix. Nat Med. 2010; 16(7):814.

120. L'heureux N, Pâquet S, Labbé R, Germain L, Auger FA. A completely biological tissue-engineered human blood vessel. FASEB J. 1998;12(1): 47-56.

121. Leeper NJ, Hunter AL, Cooke JP. Stem cell therapy for vascular regeneration: adult, embryonic, and induced pluripotent stem cells. Circulation. 2010; 122(5):517-26.

122. Thomson JA, Itskovitz-Eldor J, Shapiro SS, Waknitz MA, Swiergiel JJ, Marshall VS, et al. Embryonic stem cell lines derived from human blastocysts. Science. 1998;282(5391):1145-7.

123. Sampogna G, Guraya SY, Forgione A. Regenerative medicine: historical roots and potential strategies in modern medicine. J Microsc Ultrastruct. 2015;3(3): $101-7$.

124. Atala A. Tissue engineering for the replacement of organ function in the genitourinary system. Am J Transplant. 2004;4(s6):58-73.

125. Roubelakis MG, Pappa Kl, Bitsika V, Zagoura D, Vlahou A, Papadaki HA, et al. Molecular and proteomic characterization of human mesenchymal stem cells derived from amniotic fluid: comparison to bone marrow mesenchyma stem cells. Stem Cells Dev. 2007;16(6):931-52. 
126. Mirabella T, MacArthur J, Cheng D, Ozaki C, Woo Y, Yang M, et al. 3Dprinted vascular networks direct therapeutic angiogenesis in ischaemia. Nat Biomed Eng. 2017;1(6):0083.

127. Kim KL, Han DK, Park K, Song S-H, Kim JY, Kim J-M, et al. Enhanced dermal wound neovascularization by targeted delivery of endothelial progenitor cells using an RGD-g-PLLA scaffold. Biomaterials. 2009;30(22):3742-8.

128. Farré-Guasch E, Bravenboer N, Helder MN, Schulten EAJM, Ten Bruggenkate CM, Klein-Nulend J. Blood Vessel Formation and Bone Regeneration Potential of the Stromal Vascular Fraction Seeded on a Calcium Phosphate Scaffold in the Human Maxillary Sinus Floor Elevation Model. Materials (Basel, Switzerland). 2018;11(1):161. https://doi.org/10.3390/ma11010161.

129. Wang L, Shi Q, Dai J, Gu Y, Feng Y, Chen L. Increased vascularization promotes functional recovery in the transected spinal cord rats by implanted vascular endothelial growth factor-targeting collagen scaffold. J Orthop Res. 2018;36(3):1024-34. https://doi.org/10.1002/jor.23678.

130. Lord MS, Ellis AL, Farrugia BL, Whitelock JM, Grenett H, Li C, et al. Perlecan and vascular endothelial growth factor-encoding DNA-loaded chitosan scaffolds promote angiogenesis and wound healing. J Control Release. 2017:250:48-61. https://doi.org/10.1016/j.jconrel.2017.02.009.

131. Teo GSL, Yang Z, Carman CV, Karp JM, Lin CP. Intravital imaging of mesenchymal stem cell trafficking and association with platelets and neutrophils. Stem Cells. 2015;33(1):265-77.

132. Sivanathan KN, Gronthos S, Rojas-Canales D, Thierry B, Coates PT. Interferon-gamma modification of mesenchymal stem cells: implications of autologous and allogeneic mesenchymal stem cell therapy in allotransplantation. Stem Cell Rev Rep. 2014;10(3):351-75.

133. Kean TJ, Lin P, Caplan Al, Dennis JE. MSCs: delivery routes and engraftment, cell-targeting strategies, and immune modulation. Stem Cells Int. 2013; 2013:732742.

134. Pan Q, Zheng J, Du D, Liao X, Ma C, Yang Y, et al. MicroRNA-126 priming enhances functions of endothelial progenitor cells under physiological and hypoxic conditions and their therapeutic efficacy in cerebral ischemic damage. Stem Cells Int. 2018;2018:2912347.

135. Ngo VA, Jung J-Y, Koh J-T, Oh W-M, Hwang Y-C, Lee B-N. Leptin induces odontogenic differentiation and angiogenesis in human dental pulp cells via activation of the mitogen-activated protein kinase signaling pathway. Endod. 2018:44(4):585-91. https://doi.org/10.1016/j.joen.2017.11.018.

136. Essaadi A, Nollet M, Moyon A, Stalin J, Simoncini S, Balasse L, et al. Stem cell properties of peripheral blood endothelial progenitors are stimulated by soluble CD146 via miR-21: potential use in autologous cell therapy. Sci Rep. 2018:8(1):9387. https://doi.org/10.1038/s41598-018-27715-4.

137. Bian S, Zhang L, Duan L, Wang X, Min Y, Yu H. Extracellular vesicles derived from human bone marrow mesenchymal stem cells promote angiogenesis in a rat myocardial infarction model. J Mol Med. 2014;92(4):387-97.

138. Ibrahim AG-E, Cheng K, Marbán E. Exosomes as critical agents of cardiac regeneration triggered by cell therapy. Stem Cell Rep. 2014;2(5):606-19.

139. Feng $Y$, Huang W, Wani M, Yu X, Ashraf M. Ischemic preconditioning potentiates the protective effect of stem cells through secretion of exosomes by targeting Mecp2 via miR-22. PLoS One. 2014;9(2):e88685.

140. Zhou Y, Li P, Goodwin AJ, Cook JA, Halushka PV, Chang E, et al. Exosomes from endothelial progenitor cells improve the outcome of a murine model of sepsis. Mol Ther. 2018;26(5):1375-84. https://doi. org/10.1016/j.ymthe.2018.02.020.

141. Yang $H$, Zhang $H$, Ge S, Ning T, Bai M, Li J, et al. Exosome-derived miR-130a activates angiogenesis in gastric Cancer by targeting C-MYB in vascular endothelial cells. Mol Ther. 2018;26(10):2466-75. https://doi.org/10.1016/j. ymthe.2018.07.023.

142. Zhang W, Zhang J, Cheng L, Ni H, You B, Shan Y, et al. A disintegrin and metalloprotease 10-containing exosomes derived from nasal polyps promote angiogenesis and vascular permeability. Mol Med Rep. 2018; 17(4):5921-7.

143. Shen Y, Liu X, Huang Z, Pei N, Xu J, Li Z, et al. Comparison of magnetic intensities for mesenchymal stem cell targeting therapy on ischemic myocardial repair: high magnetic intensity improves cell retention but has no additional functional benefit. Cell Transplant. 2015;24(10):1981-97.

144. Hu Y, E H, Yu X, Li F, Zeng L, Lu Q, et al. Correlation of quantitative parameters of magnetic resonance perfusion-weighted imaging with vascular endothelial growth factor, microvessel density and hypoxiainducible factor-1a in nasopharyngeal carcinoma: Evaluation on radiosensitivity study. Clin Otolaryngol. 2018;43(2):425-33. https://doi. org/10.1111/coa.12982.
145. Balint R, Cassidy NJ, Cartmell SH. Electrical stimulation: a novel tool for tissue engineering. Tissue Eng B Rev. 2012;19(1):48-57.

146. Toma C, Fisher A, Wang J, Chen X, Grata M, Leeman J, et al. Vascular endoluminal delivery of mesenchymal stem cells using acoustic radiation force. Tissue Eng A. 2011;17(9-10):1457-64.

147. Hanawa K, Ito K, Aizawa K, Shindo T, Nishimiya K, Hasebe Y, et al. Lowintensity pulsed ultrasound induces angiogenesis and ameliorates left ventricular dysfunction in a porcine model of chronic myocardial ischemia. PloS One. 2014;9(8):e104863-e. https://doi.org/10.1371/journal.pone.0104863.

148. Bhise NS, Shmueli RB, Sunshine JC, Tzeng SY, Green JJ. Drug delivery strategies for therapeutic angiogenesis and antiangiogenesis. Expert Opin Drug Deliv. 2011;8(4):485-504. https://doi.org/10.1517/17425247.2011.558082.

149. Park H-J, Jin Y, Shin J, Yang K, Lee C, Yang HS, et al. Catechol-functionalized hyaluronic acid hydrogels enhance angiogenesis and osteogenesis of human adipose-derived stem cells in critical tissue defects. Biomacromolecules. 2016; 17(6):1939-48. https://doi.org/10.1021/acs.biomac.5b01670.

150. Health Nlo. Estimates of funding for various research, condition, and disease categories (RCDC). See https://reportnihgov/rcdc/categories nih gov/rcdc/ categories/(last Accessed 17 Feb 2012). 2013.

151. Choi C, Kim HM, Shon J, Park J, Kim H-T, Kang SH, et al. The combination of mannitol and temozolomide increases the effectiveness of stem cell treatment in a chronic stroke model. Cytotherapy. 2018;20(6):820-9. https://doi.org/10.1016/j.jcyt.2018.04.004.

152. Gonzales-Portillo GS, Sanberg PR, Franzblau M, Gonzales-Portillo C, Diamandis T, Staples M, et al. Mannitol-enhanced delivery of stem cells and their growth factors across the blood-brain barrier. Cell Transplant. 2014;23(4-5):531-9. https://doi.org/10.3727/096368914×678337.

153. Pachence JM. Collagen-based devices for soft tissue repair. J Biomed Mater Res A. 1996;33(1):35-40,

154. Xia X, Li J, Xia B, Yang H, Zhang D, Zhou B, et al. Matrigel scaffold combined with ad-hBMP7-transfected chondrocytes improves the repair of rabbit cartilage defect. Exp Ther Med. 2017;13(2):542-50.

155. Costa NL, Sher P, Mano JF. Liquefied capsules coated with multilayered polyelectrolyte films for cell immobilization. Adv Eng Mater. 2011;13(6): B218-24.

156. Costa RR, Testera AM, Arias FJ, Rodríguez-Cabello JC, Mano JF. Layer-by-layer film growth using polysaccharides and recombinant polypeptides: a combinatorial approach. J Phys Chem B. 2013;117(22):6839-48.

157. Tsai M-C, Hung K-C, Hung S-C, S-h H. Evaluation of biodegradable elastic scaffolds made of anionic polyurethane for cartilage tissue engineering. Colloids Surf B: Biointerfaces. 2015;125:34-44.

158. Tan H, Chu CR, Payne KA, Marra KG. Injectable in situ forming biodegradable chitosan-hyaluronic acid based hydrogels for cartilage tissue engineering. Biomaterials. 2009:30(13):2499-506.

159. Bonauer A, Carmona G, Iwasaki M, Mione M, Koyanagi M, Fischer A, et al. MicroRNA-92a controls angiogenesis and functional recovery of ischemic tissues in mice. Science. 2009;324(5935):1710-3.

160. Kalinina N, Klink G, Glukhanyuk E, Lopatina T, Efimenko A, Akopyan Z, et al. miR-92a regulates angiogenic activity of adipose-derived mesenchymal stromal cells. Exp Cell Res. 2015;339(1):61-6.

161. Liu Y, Luo F, Wang B, Li H, Xu Y, Liu X, et al. STAT3-regulated exosomal miR-21 promotes angiogenesis and is involved in neoplastic processes of transformed human bronchial epithelial cells. Cancer Lett. 2016;370(1):125-35.

162. Mao G, Liu Y, Fang X, Liu Y, Fang L, Lin L, et al. Tumor-derived microRNA494 promotes angiogenesis in non-small cell lung cancer. Angiogenesis. 2015;18(3):373-82.

163. Kucharzewska P, Christianson H, Welch J, Svensson K, Fredlund E. M. 600 Ringner, M. Morgelin, E. Bourseau-Guilmain, J. Bengzon, and M. Belting. 2013. 601 Exosomes reflect the hypoxic status of glioma cells and mediate hypoxia-dependent 602 activation of vascular cells during tumor development. Proc Natl Acad Sci USA.110:7312-7. 